\title{
A Key to Genera of Iranian Lady Beetles (Coleoptera: Coccinellidae) and Species of Subfamilies Chilocorinae, Coccinellinae, Epilachinae and Microweiseinae
}

\author{
R. ABDOLAHI ${ }^{1 *}$, O. NEDVĚD ${ }^{2}$ and J. NOZARI ${ }^{1}$ \\ ${ }^{1}$ Department of Plant Protection, College of Agriculture and Natural Resources, \\ University of Tehran, Karaj, P.O.Box 31587-77871, Iran \\ ${ }^{2}$ Faculty of Science, Institute of Entomology, Biology Center, \\ University of South Bohemia, Branišovská 31, 37005 České Budějovice, Czechia
}

(Received: 4 January 2017; accepted: 24 February 2017)

\begin{abstract}
A key to genera of Iranian Coccinellidae, besides species of subfamilies Chilocorinae, Coccinellinae, Epilachinae and Microweiseinae is given.
\end{abstract}

Keywords: Lady beetle, key, Iran.

Lady beetles or ladybirds, as the largest family in the newly recognized superfamily Coccinelloidea (Robertson et al. 2015) with about 6000 species described worldwide (Iablokoff-Khanzorian 1982; Vandenberg 2002), are well known as mostly beneficial predators of aphids, scale insects and mites. Also, some species of ladybirds are so sensitive to changes in the environment that could be considered as evaluation factors of the health of ecosystems (Iperti 1999), which increases their importance in the nature. Nevertheless, some of them are mycophagous and phytophagous which could be sometimes considered as a pest (Dobzhansky 1933).

According to the last checklist of the family in Iran (Abdolahi et al. 2016) there are 142 species classified in 8 subfamilies, 17 tribes and 41 genera in the country which demonstrates a high diversity of genera and species in Iran. So, according to high amount of lady beetle species in Iran, it seems necessary to providing a comprehensive key to identifying of the genera and species.

Although there are many literatures related to fauna of Iranian Coccinellidae, mostly they were faunistic reports without any appropriate key, even to the Iran subfamilies. Many of Iranian lady beetle species are really rare and have been described since many years ago. For many species, particularly rare species, literatures are too old and not available in internet. Also, for many species descriptions are not in English. Maybe that is why there was not any key to Iranian lady beetles so far, even to subfamilies and

* Corresponding author; e-mail: Rahim.abdolahi@ut.ac.ir 
tribes. For this purpose this paper is an attempt to provide a key to genera of Iranian lady beetles, besides species of the subfamilies Chilocorinae, Epilachinae, Microweiseinae and Coccinellinae.

\section{Materials and Methods}

According to the last classification of Coleoptera, Coccinellidae has been classified in two subfamilies Microweiseinae and Coccinellinae (Bouchard et al. 2011) but we used the classification of (Kovár 2007) modified by (Nedvěd and Kovář 2012) in this paper.

This list incorporated the most recent systematic and nomenclature updates. The arrangement of the subfamilies, tribes and genera do not reflect phylogenetic relationships.

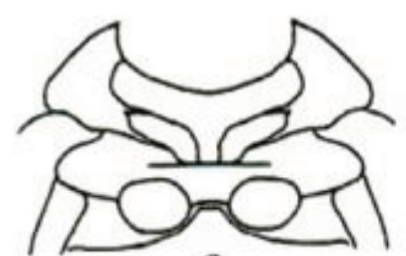

a

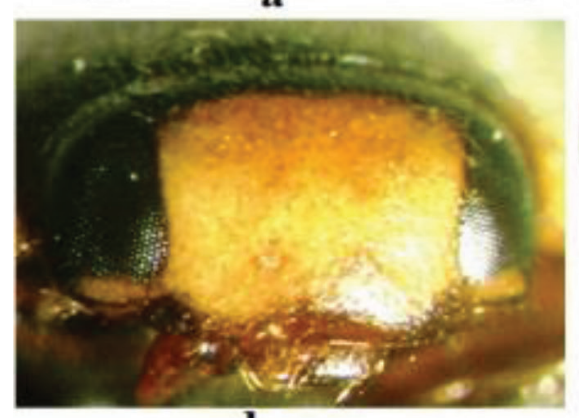

d

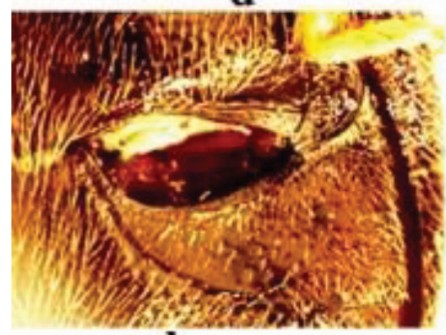

h

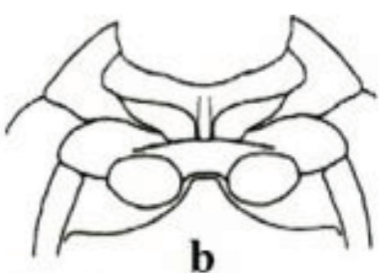

b
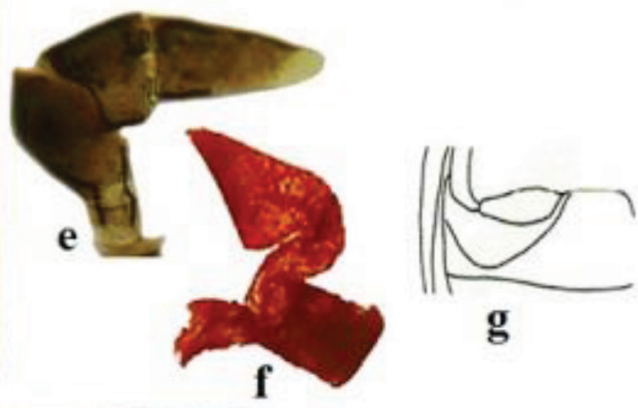

g
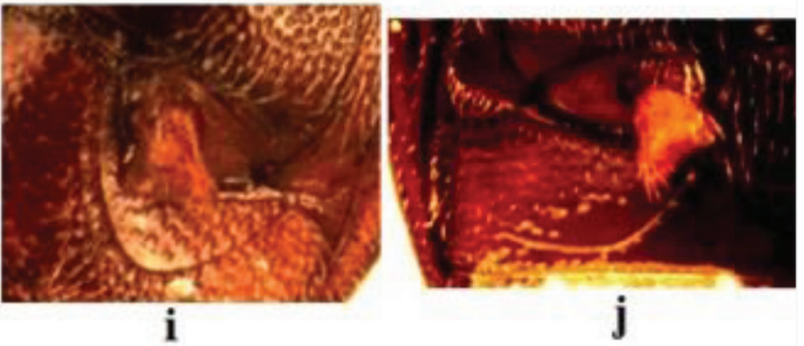

Fig. 1. a-c: Prosternum and mesosternum; a: genus Adalia, b: genus Coccinula; c: genus Cryptolemus; d: clypeus in genus Platynaspis; e-f: maxillary palp; e: genus Pharoscymnus, f: genus Adalia; $\mathrm{g}-\mathrm{j}$ : postcoxal line; g: genus Scymniscus, h and i: genus Scymnus, j: genus Nephus 


\section{Results}

Key to genera and species of Iranian lady beetles of subfamilies Chilocorinae, Coccinellinae, Epilachinae and Microweiseinae

1. Mandibles with four or more large separated teeth..... Epilachinae, Epilachini 8 - Mandibles with one or two apical teeth

2. (1) - Clypeus anteriorly extending and covering anterior margin of eye and the basal part of antenna in front view (Fig. 1d) .................................................. 3

- Clypeus does not extend and not cover basal part of antenna ..................... 4

3. (2) - Body rounded; lateral margins of elytra explanate; mandibles with a single apex; body glabrous or sparsely hairy Chilocorinae, Chilochorini 10 - Body oval; elytra on sides simple; mandibles with two apical teeth; body covered in dense hairs.

Scymninae, Platynaspidini, Platynaspis luteorubra (Goeze, 1777)

4. (2) - Distal segment of maxillary palp elongate and oval (Fig. 1e).

Sticholotidinae and Microweiseinae 22

- Distal segment of maxillary palp with different shape, mostly ax-shaped

(Fig. 1f)

5. (4) - Antenna usually longer than $2 / 3$ head width ......................................... 6

- Antenna as long as $2 / 3$ head width or shorter.... Scymninae 25

6. (5) - Elytra and pronotum smooth Coccinellinae 31

- Elytra and pronotum pubescent

7. (6) - Antenna longer than $2 / 3$ head width and shorter than whole head width; eyes big and finely faceted.

Ortaliinae Mulsant, 1850; Noviini Mulsant, 1850; Rodolia Mulsant, 1850

- Antenna longer than head width; eyes coarsely faceted ........ Coccidulinae 60

8. (1) - Body size 3-5 mm, lateral margins of pronotum straight

- Body size 6-9 mm, lateral margins of pronotum non-straight

9. (8) - Scutellum black, pronotum usually with a black spot

Subcoccinella vigintiquatuorpunctata (Linnaeus, 1758)

- Scutellum light, pronotum without spot ... Cynegetis syriaca Chevrolat, 1836

10. (8) - Each elytron with 6 black spots, one spot joined to scutellum and elytral suture

Henosepilachna argus (Geoffroy, 1785)

- Each elytron with 6 black spots without joining to scutellum and elytral suture Chnootriba elaterii P. Rossi, 1794

10. (3) - Body strongly rounded and convex; frontal plate emarginated at anterior margin; femoral line forming quarter of a circle

Chilocorus bipustulatus (Linnaeus, 1758)

- Body oval to round; frontal plate not emarginated; femoral line forming half a circle

11. (10) - Antenna 8-segmented ............ Brumoides adenensis E. A. Chapin, 1965

- Antenna 10-segmented

12. (11) - Scutellum more than 20 times narrower than body; legs black-brown, elytra usually with spots Exochomus Redtenbacher, 184413 
- Scutellum 16 times narrower than body; legs yellowish-red; elytra always black without any spots Parexochomus Barovskij, 192219

13. (12) - Elytra with two oblique blackish strips Exochomus bifasciatus (Barovskij, 1927)

- Elytra with different patterns 14

14. (13) - Elytra spots long and strip-shaped, rarely without spot .................... 15

- Elytra spots small, almost circular-shape............................................... 16

15. (14) - Elytra with or without spots, background of elytra blackish, spots and strips brownish, in case of absence of spots elytra completely brownish, Basal lobe shorter than paramere

Exochomus quadripustulatus (Linnaeus, 1758)

- Elytra with spots and stripes, background of elytra brownish, spots and stripes blackish, basal lobe as long as paramere or a little longer

Exochomus undulatus (Weise, 1878)

16. (14) - Elytra blackish, each elytron with two spots

Exochomus quadriguttatus (A. Fleischer, 1900)

- Elytra brownish, each elytron with more than two spots

17. (16) - Most parts of pronotum brownish, with a black spot in middle Exochomus octosignatus (Gebler, 1830)

- Most parts of pronotum blackish 18

18. (17) - Middle spot of elytra elongate, basal lobe shorter than paramere Exochomus gebleri (Weise, 1885) - Middle spot of elytra not elongate, basal lobe as long as paramere or a little longer Exochomus kiritschenkoi (Barovskij, 1927)

19. (12) - Body smooth and without hair ....................................................... 20

- Body hairy

20. (19) - Pronotum completely yellowish

Parexochomus nigripennis (Erichson, 1843)

- Only lateral margins of pronotum yellowish

Parexochomus nigromaculatus (Goeze, 1777)

21. (19) - Body with dense hairs, basal lobe apically subulate, elytra margins further brownish. Parexochomus pubescens (Kuster, 1848)

- Body usually with spare hairs, basal lobe apically finger-shaped, elytra margins further blackish .... Parexochomus melanocephalus (Zoubkoff, 1833)

22. (4) - Body smooth or with spare hairs, prosternum covering mouth part

Serangiini, Serangium montazerii Fursch, 1995

- Body pubescent, prosternum not covering mouth part

23. (22) - Prosternum extended.

Microweiseini, Paracoelopterus berytensis J. Weise, 1884

- Prosternum not extended

24. (23) - Elytra without spots

Sticholotidini, Coelopterus salinus Mulsant and Rey, 1852

- Elytra with spots Sticholotidini, Pharoscymnus Bedel, 1906 
25. (5) - Pronotum and elytra smooth

Hyperaspidini, Hyperaspis Chevrolat, 1837

- Pronotum and elytra pubescent

26

26. (25) - Anterior margin of prosternum lobed, at least partially concealing mouthparts; all hairs on elytra directed posteriorly; body size 1-1.5 mm (Fig. 1c) Stethorini, Stethorus Mulsant, 1850

- Anterior margin of prosternum not lobed 27

27. (26) - Postcoxal line joining hind margin of the first abdominal ventrite, apex not recurved Diomini, Diomus rubidus Motschulsky, 1837

- Postcoxal line complete or incomplete, not joining hind margin of first abdominal sternum, apex recurved Scymnini 28

28. (27) - Hairs in the hind third of elytra directed obliquely from the elytral suture 29

- Hairs in the hind part of elytra directed parallel to elytral suture ........... Clitostethus arcuatus (Rossi, 1794)

29. (28) - Prosternal process wide and smooth, without carinae; distal part of postcoxal line parallel with abdominal segment margin and only slightly recurved (Fig. 1j) Nephus Mulsant, 1846

- Prosternal process narrow, with carinae; distal part of postcoxal line not parallel with abdomen segment margin, clearly recurved 30

30. (29) - Postcoxal line reaching lateral margin of abdominal segment (Fig. 1g)..... Scymniscus Dobzhansky, 1925 - Postcoxal line reaching anterior margin of abdominal segment (Fig. 1i) or incomplete (Fig. 1h) Scymnus Kugelann, 1794

31. (6) - Antenna 1.5 to two times longer than head width; mandibles with a row of small teeth below apex Halyziini 32 - Antenna shorter than 1.5 times as head width; mandibles without row of small teeth Tytthaspidini and Coccinellini 34

32. (31) - Elytral spots black ................................... Psyllobora Dejean, 183647

- Elytral spots white 33

33. (32) - Eight spots on each elytron; body flat

- Six spots on each elytron; body convex

Halyzia sedecimguttata (Linnaeus, 1758)

Vibidia duodecimguttata (Poda in Neuhaus, 1761)

34. (33) - Elytra spots quite quadrate

Propylea quaturodecimpunctata (Linnaeus, 1758)

- Elytra spots rounded or irregular

35. (34) - Pronotum black with light spots in the anterior corners ....................... 36

- Pronotum with different patterns ......................................................... 37

36. (35) - Femoral line bifurcate; antenna as long as frons width ...........................

Coccinella Linnaeus, 175848

- Femoral line not bifurcate, antenna longer than frons width

Ceratomegilla undecimnotata D. H. Schneider, 1792 
37. (35) - Distal parts of femora distinctly visible beyond body in dorsal view

Hippodamia Chevrolat, 1836

- Distal parts of femora barely visible beyond body in dorsal view 38

38. (37) - Body distinctly flat Aphidecta obliterate (Linnaeus, 1758)

- Body convex or relatively flat 39

39. (38) - Pronotum with anchor-shaped spot

.Menochilus sexmaculatus (Fabricius, 1781)

- Pronotum without anchor-shaped spot

40. (39) - Each elytron with 4 spots near to elytral suture, one spot in anterior lateral margin and one zigzag-shaped strip in margin

- Elytra with different patterns

Tytthaspis sedecimpunctata (Linnaeus, 1758)

41. (40) - Body relatively elongate and flat

Anisosticta Dejean, 1837 (in Iran including three species: A. caucasica Fleischer, 1900; A. bitriangularis (Say, 1842) and A. novemdecimpunctata (Linnaeus, 1758))

- Body oval

42. (41) - Antenna longer than head width; elytra usually with light spots Calvia Mulsant, $1850 \quad 53$

- Antenna shorter than head width; elytra spots are not white ...................... 43

43. (42) - Claw with tooth at base .................................................................. 44

- Claw simple, without tooth, body strongly convex with dense punctuation, mandibles with fine serration below two apical tips

Bulaea lichatschovii Hummel, 1827

44. (43) - Prosternum flat, mesosterrnum with excision for prosternal process.... 45

- Prosternum convex without carinae (Fig. 1a); mesosternum straight anteriorly (Fig. 1a) Adalia Mulsant, 184654

45. (44) - Prosternum with carinae (Fig. 1b), anterior margin of mesosternum straight, emarginated (Fig. 1b), spurs on mid and hind tibia long Coccinula Dobzhansky, 192556

- Anterior margin of mesosternum more or less excised, spurs on mid and hind tibia short or missing 46

46. (45) - Tibia with short spurs; body size 3-5.4 mm

Oenopia Mulsant, $1850 \quad 58$

- Tibia without spurs; body size 5-8 mm

Harmonia quadripunctata (Pontoppidan, 1763)

47. (32) - Each elytron with 10 spots, pronotum with spot

Psyllobora vigintiduopunctata (Linnaeus, 1758)

- Each elytron with 8 spots, pronotum without spot. Psyllobora bisoctonotata (Mulstant, 1850)

48. (36) - Elytra with L-shaped spot Coccinella iranica Dobzhansky, 1926

- Elytra without L-shaped spot 
49. (48) - Body length 5.3-7.6 mm, elytra with at most seven spots Coccinella septempunctata Linnaeus, 1758 - Body length $5 \mathrm{~mm}$, elytra with 11 spots 50

50. (49) - Basal lobe with a warhead-shaped structure in distal part, elytra spots large, rare. Coccinella magnopunctata Rybakow, 1889 - Basal lobe without a warhead-shaped structure in distal part Coccinella undecimpunctata Linnaeus, 1758

51. (37) - Pronotum with three spots, one large spot in the middle and two small spots in the margins

Hippodamia tredecimpunctata (Linnaeus, 1758)

- Pronotum with a large black spot 52

52. (51) - Pronotum spot crown-shaped with a depression in the middle and sometimes in the lateral margins, sipho with a warhead-shaped structure in the sub-apical part. Hippodamia variegata (Goeze, 1777) - Pronotum spot large, without depression and covering most of pronotum Hippodamia septemmaculata (DeGeer, 1775)

53. (42) - Elytra without spot or at most with 6 spots

Calvia punctata (Mulsant, 1853) - Elytra with 14 spots ................ Calvia quaturodecimguttata (Linnaeus, 1758)

54. (44) - Basal lobe from lateral view sword-shaped with a depression in the upper middle part Adalia tetraspilota (Hope, 1831)

- Basal lobe not sword-shaped from lateral view .... 55

55. (54) - Scutellum, usually mesoepimeron and sometimes mesonotum light or brownish Adalia decempunctata (Linnaeus, 1758) - Scutellum, mesonotum and mesoepimeron black

Adalia bipunctata (Linnaeus, 1758)

56. (45) - Polymorphic in elytra pattern, basal lobe shorter than paramere

Coccinula elegantula (Weise, 1890)

- Polymorphic in elytra pattern, basal lobe almost as long as paramere.

57. (56) - Pronotum spot large, black and covering most parts of pronotum

Coccinula sinuatomarginata Faldermann, 1837

- Pronotum with different pattern Coccinula redimita (Weise, 1885)

58. (46) - Elytra with a I-shaped spot Oenopia montana Savoyskaya, 1969

- Elytra spots with different shapes

59. (58) - Middle spot of elytra extending toward elytral suture Oenopia conglobate (Linnaeus, 1758)

- Polymorphic in elytra pattern Oenopia oncina (Olivier, 1808)

60. (7) - Antenna ten-segmented; tarsus visibly 4-segmented

Tetrabrachini, Tetrabrachys Kapur, 1948

- Antenna eleven-segmented; tarsus virtually with three segments Coccidulini 61

61. (60)-Anterior margin of prosternum lobed-shaped, at least partially concealing mouthparts (Fig. 1c) Cryptolaemus montrouzieri Mulsant, 1853

- Anterior margin of prosternum not concealing mouthparts 
62. (61) - Body $1.6 \times$ longer than wide; pronotum widest at hind margin Lindorus lophantae Blaisdéll, 1892 - Body twice longer than wide; pronotum widest in middle or at anterior half .... Coccidula Kugelann, 1798

\section{Acknowledgements}

We are grateful to Dr. Ebrahim Sadeghi, Dr. Mostafa Mirzaei, M.s Raheleh Salehi and Dr. Mehdi Zareh Khormizi for providing some literatures.

\section{Literature}

Abdolahi, R., Nozari, J., Allahyari, H. and Khormizi, M. (2016): Checklist and distribution of lady beetles (Coleoptera: Coccinellidae) in Iran. Iranian J. Animal Biosystematics 12, 1-35.

Bouchard, P., Bousquet, Y., Davies, A. E., Alonso-Zarazaga, M. A., Lawrence, J. F., Lyal, C. H. C., Newton, A. F., Reid, C. A. M., Schmitt, M., Ślipiński, S. A. and Smith, A. B. T. (2011): Family-group names in Coleoptera (Insecta). ZooKeys 88, 1-972.

Dobzhansky, T. (1933): Geographical variation in lady-beetles. American Naturalist 67, 97-126.

Iablokoff-Khanzorian, S. M. (1982): Les Coccinelles. Coléoptères-Coccinellidae. In: Société Nouvelles. Boubée Press, Paris, 568 p.

Iperti, G. (1999): Biodiversity of predaceous Coccinellidae in relation to bioindication and economic importance. Agriculture, Ecosystems and Environmen 74, 323-342.

Kovář, I. (2007): Coccinellidae. In: I. Löbl and A. Smetana (eds): Catalogue of Palaearctic Coleoptera. Vol. 4. Stenstrup, Apollo Books, pp. 568-631.

Nedvěd, O. and Kovář, I. (2012): Phylogeny and classification. In: I. Hodek, H. van Emden and A. Honěk (eds): Ecology and Behaviour of the Ladybird Beetles (Coccinellidae). Wiley-Blackwell, Oxford pp. 1-12.

Robertson, J. A., Ślipiński, A., Moulton, M., Shockley, F. W., Giorgi, A., Lord, N. P. and Whiting, M. F. (2015): Phylogeny and classification of Cucujoidea and the recognition of a new superfamily Coccinelloidea (Coleoptera: Cucujiformia). Systematic Entomology 40, 745-778.

Vandenberg, N. J. (2002): Coccinellidae Latreille 1807. In: R. H. Jr. Arnett, M. C. Thomas, P. E. Skelley, and J. H. Frank (eds): American Beetles 2, Polyphaga: Scarabaeoidea through Curculionoidea. CRC Press, Boca Raton, New York, pp. 371-389. 